Edith Cowan University

Research Online

ECU Publications 2013

$1-1-2013$

Do political instability, terrorism, and corruption have deterring effects on tourism development even in the presence of unesco heritage? A cross-country panel estimate

Ghialy Choy Lee Yap

Edith Cowan University

Shrabani Saha

Edith Cowan University

Follow this and additional works at: https://ro.ecu.edu.au/ecuworks2013

Part of the Tourism and Travel Commons

10.3727/108354213X13782245307911

This is an Accepted Manuscript of an article published by Cognizant Communication Corporation on November 1 , 2013 : Yap, G. , \& Saha, S. (2013). Do political instability, terrorism, and corruption have deterring effects on tourism development even in the presence of unesco heritage? A cross-country panel estimate. Tourism Analysis, 18(5), 587-599. Original article available online here This Journal Article is posted at Research Online. https://ro.ecu.edu.au/ecuworks2013/894 


\title{
DO POLITICAL INSTABILITY, TERRORISM, AND CORRUPTION HAVE DETERRING EFFECTS ON TOURISM DEVELOPMENT EVEN IN THE PRESENCE OF UNESCO HERITAGE? A CROSS-COUNTRY PANEL ESTIMATE
}

\author{
GHIALY YAP AND SHRABANI SAHA \\ School of Accounting, Finance and Economics, Faculty of Business and Law, \\ Edith Cowan University, Joondalup, WA, Australia
}

\begin{abstract}
This article evaluates the effects of political instability, terrorism, and corruption on tourism development, particularly UNESCO-listed heritage destinations. Using a fixed-effects panel data analysis for 139 countries over the period 1999-2009, the result reveals that a one-unit increase in political instability decreases tourist arrivals and tourism revenue between $24 \%$ and $31 \%$ and $30 \%$ and $36 \%$, respectively. Furthermore, in the presence of heritage, terrorism has negative effects on tourism demand even though its effect is lower than that of political instability. However, the study shows that an increase in corruption index would not have an adverse influence on tourist arrival numbers, particularly for those countries that have historical and natural heritage. Perhaps, many experienced travelers have expectations that they would require paying bribes to corrupt authorities for travel visa or permits to some tourist destinations in order to make things accessible. Moderation effect results indicate that political instability reduces tourism demand even in UNESCO-listed heritage destinations.
\end{abstract}

Key words: Political instability; Corruption; Tourism; Panel data analysis

Introduction

For most countries, particularly developing economies, tourism plays an important role in generating employment opportunities and revenues. Because tourism is a labor-intensive industry, many job activities are related to the supply chain of the sector such as food delivery services, production and sale of handicrafts, recreational activities, and construction of tourism infrastructures (United Nations World
Tourism Organization, 2006). For those developing countries that have abundant labor supply, tourism is considered as an industry that can alleviate poverty and create jobs to financially support the poor.

Nevertheless, similar to any business, tourism is considerably sensitive to political environment. When a country experiences stable governance and sound political system, it encourages more national and foreign investments in physical buildings 
(i.e., hotels and infrastructures) and in services (i.e., marketing campaign and security). Such tourism investment not only promotes the country's economic growth but can also create a positive destination's image as a safe and comfortable place to travel. Hall and O'Sullivan (1996) quoted that "issues of political stability and political relations within and between states are extremely important in determining the image of destinations in touristgenerating regions and ... the real and perceived safety of tourists" (p. 105). When a country experiences political upheaval and terrorist-related incidence, potential tourists may be warned not to visit the country and that could significantly affect its tourism industry. Although most studies would probably agree that political instability and terrorism discourage the tourism industry, the magnitude of these effects looking at the UNESCO's listed heritage countries has yet to be measured. In order to fill this gap, we evaluate the impacts using wellknown and widely used political risk data from International Country Risk Guide for the period 1999-2009.

Like political instability and terrorism, corruption can adversely affect a country's tourism industry as revealed by the tourism literature (Das \& Dirienzo, 2010; Lau \& Hazari, 2011). Das and Dirienzo (2010) argued that if a country practices bribery and fraudulent business practice, this can deteriorate its social and cultural image and impede its tourism competitiveness. Moreover, political inconsistency arising from the constant change of governments could raise the cost of doing business in corrupted countries and generate barriers for investments in tourism (Tosun \& Timothy, 2001). A politically corrupt nation can indirectly exacerbate public turmoil when conflicts between corrupt politicians and the people of the country and/or opposition political parties become intense. One of the recent incidents is the ousting of Egypt's former regime in 2011 where the incident witnessed days of blood demonstrations and chaos (Lagi, Bertrand, \& Bar-Yam, 2011). Even though the country's political revolution is currently over, Euromonitor (2011) projected that its tourist arrival number is predicted to decline by $2 \%$ in 2012 as potential tourists are still wary of traveling to Egypt.

The literature suggests that political instability has adverse effects on tourism (e.g., Issa \& Altinay,
2006; Neumayer, 2004; Sönmez, 1998); however, whether terrorism and corruption will affect tourists' decisions to travel still remains puzzling. Tourists in modern days would prefer new travel experience particularly to those Third World destinations that may have considerably high level of corruption but may not necessarily be politically unstable. Mowforth and Munt (2009) found that between 2000 and 2004, the number of tourist arrivals to African, Asia Pacific, and Middle East countries increased by $4.4 \%, 6.9 \%$, and $9.5 \%$ per annum, respectively, whereas the annual growth rate of tourist arrivals to European and American countries was just $2.7 \%$ and $-0.5 \%$, respectively (pp. 93-94). They asserted that the new global travel patterns can be related to the rising middle class in the middleincome economies and the attractive travel package offered by these Third World destinations with good value for money. Also, perhaps the modern tourists prefer destinations that can offer more prestigious tourism products (i.e., UNESCO heritage).

Figure 1 illustrates the average political instability and corruption indices as well as the tourism growth rate from 1999 to 2009 and presents some interesting findings. Highly corrupt and terrorist-prone countries have a relatively high level of tourist growth rate. For instance, tourist arrivals to Uganda grew approximately by $17 \%$ annually between 1999 and 2009 despite the country's high corruption and terrorism indices. Similarly, India is classified as one of the most corrupt countries; but its tourist number grew by $7.9 \%$ yearly. In contrast, those countries that are relatively stable and less corrupt tend to have low tourism growth. For example, Switzerland is considered as one of the safest countries in the world with low levels of political instability, terrorism, and corruption; however, its tourism was recorded at merely $1.2 \%$ annual growth during 1999 and 2009. Therefore, on the basis of the above arguments, could a tourist choose a travel destination depending more on tourism products and less on the destination's political environment or both?

In addressing the inquiry into the impact of political instability, terrorism, and corruption on tourism, with a few exceptions, the majority of the empirical studies have examined various country and/or regional case studies but cross-sectional comparative analysis has been lacking (such as 

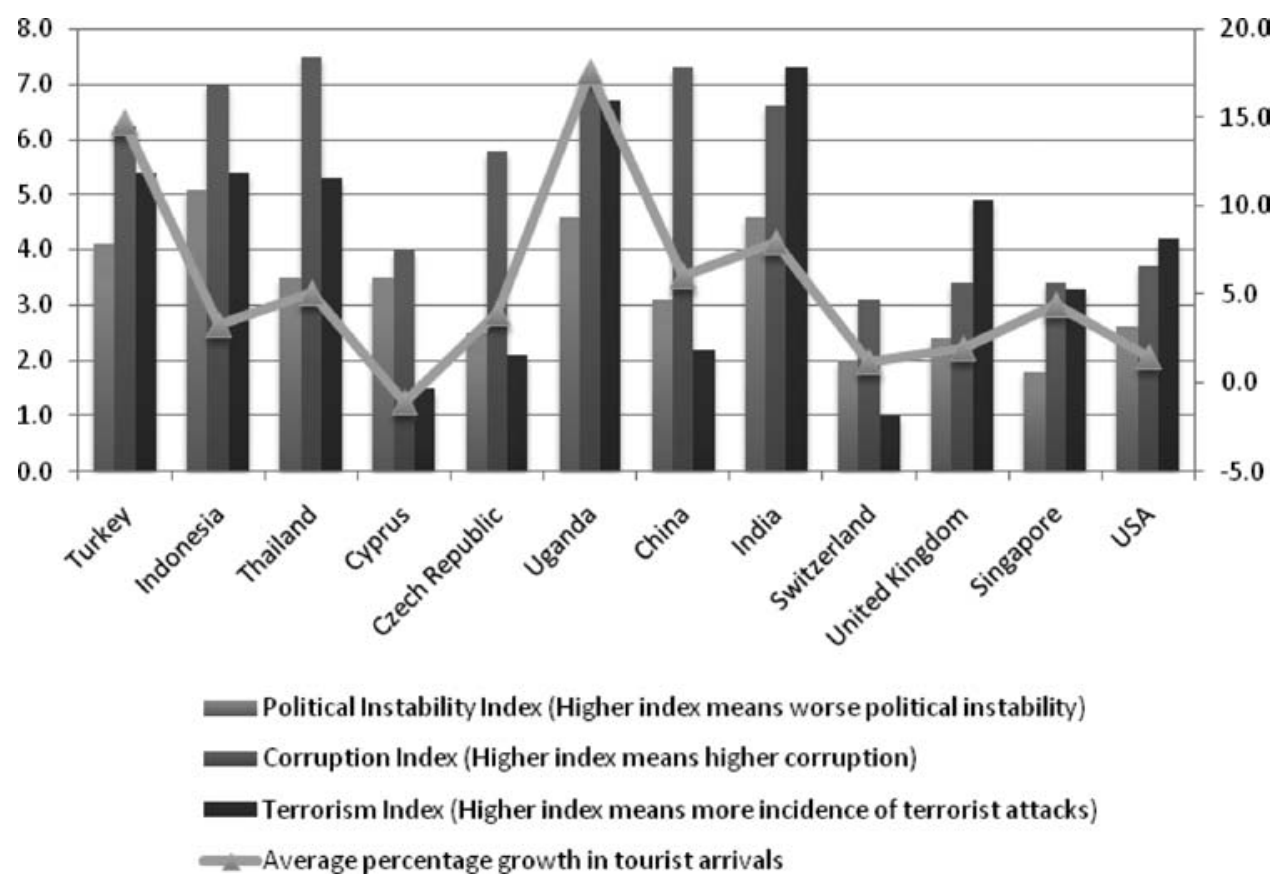

Figure 1. Political instability, corruption, terrorism, and tourism growth (average between 1999 and 2009) for selected countries. Source: International Country Risk Guide (ICRG) and Euromonitor.

Hoti, McAleer, \& Shareef, 2005; Narayan, 2005; Neumayer, 2004). Moreover, to the best of our knowledge, there is no single empirical study that investigates the impact of political instability, terrorism, and corruption on tourism demand in the presence of historical and natural heritage. Garrod and Fyall (2000) asserted that a country’s heritage has a highly economic potential for generating tourism revenue and sustaining the industry. Hence, our research question is whether those destinations that have world-renowned heritage are able to attract tourists even in the presence of political instability. While examining the issue we employed panel data analysis because it combines cross-sectional and time-series data and can produce more reliable estimates (Baltagi, 2008).

The main contribution of this article is to distinguish the effects of political risks on tourism development especially in those vulnerable UNESCOlisted heritage destinations. It aims to provide a projection of the costs of political instability, terrorism, and corruption on tourism demand for these destinations. Furthermore, the key motivation of modeling tourism demand is to determine business profitability, and hence, estimates of expected future demand constitute an important element in all planning of tourism activities particularly for perishable tourism products (Song \& Witt, 2006). Therefore, it is crucial that a demand model should incorporate political risk indicators that evidently play a significant influence on tourism businesses (e.g., Hoti, McAleer, \& Shareef, 2007; Neumayer, 2004), especially in countries that contain UNESCO-listed heritage. The model not only aims to generate accurate tourism forecasts but also to give correct estimations of the long-term financial commitments to rebuild and sustain heritage tourism in highly political unstable countries.

\section{Political Instability, Corruption, and Heritage Tourism: A Brief Overview}

Political instability can be viewed in three perspectives. First, it is the propensity for regime or government change; second, it can be related to the political upheaval or violence in a society; and third, it focuses on instability in government policies that are subject to frequent changes (Darity, 2008, 
pp. 304-306). Political instability can be related to terrorism, riots, and wars (Sönmez, 1998), and its effects can deter a country's tourism growth. Politically unstable countries constantly encounter challenges such as withdrawal of foreign investments and negative public image when the governments try to implement tourism planning strategies (Issa \& Altinay, 2006).

The existing literature of political crises has shown evidence that political instability can hinder tourism development and damage economic growth. When a regime is being challenged for its political legitimacy from outside the political system, the intensity of the challenge would rise and provoke public violence and turmoil if the government fails to implement mutual resolutions (Neumayer, 2004). Hall and O’Sullivan (1996) argued that prolonged political unrests can negatively influence tourists' perceptions on the affected destinations and that would discourage potential tourists to visit the countries as well as its neighboring regions (p. 105). Moreover, they asserted that if a country experiences a military coup or warfare, military activities can destroy tourist infrastructure and limit tourists' comfort and convenience in traveling (Hall \& O’Sullivan, 1996, p. 108). With the decline in tourist numbers in a politically problematic country, investments on the tourism industry will be affected and there is a tendency for the government to divert tourism investment resources to fund military activities.

Terrorism can be categorized in two ways. First, political instability can lead to terrorism when a civil society is denied the freedom of expressing political discontent, leading the society to exert political pressure against the government and make terrorism more likely (Munson, 2008). Second, a country that experiences terrorist attacks may not necessarily relate to home politics. Franks (2009) argued that some cases of terrorism threats can originate from al-Qaeda-type organizations that have no direct relation with those affected countries. Tourists' safety is always vulnerable to terrorist-related incidents and internal conflicts in host countries. In the tourism literature, most empirical research reveals that tourism is susceptible to terrorism acts, particularly if terrorist attacks happen in developing countries (Baker \& Coulter, 2007; Bhattarai, Conway, \& Shrestha, 2005; Llorca-Vivero, 2008; Thompson, 2011; Yaya, 2009).
Furthermore, Pizam and Fleischer (2002) asserted that if a destination suffers from frequent terrorist attacks, its number of international tourist arrivals will constantly decline until its tourism industry eventually reaches a standstill.

However, political events such as a coup and internal political problems have far more severe impacts on tourism activity than one-off terrorist attack incidents (Fletcher \& Morakabati, 2008). Similarly, Neumayer (2004) found that a substantial increase in terrorist events lowers tourist arrivals by $8.8 \%$; however, a substantial increase in human rights violation reduces tourist arrivals by $32 \%$. In conclusion, the literature suggests that political conflict events have more severe impacts on tourism than terrorist attack incidents.

In relation to public sector corruption, it can be a barrier to tourism development. Duffy (2000) argued that the corrupt governments have the wealth, status, or power to intervene in tourism projects and allocate resources that could render benefits to them personally. He further justified that these governments may allow illegitimate foreign investment in tourism developments; that is, hotels and tourism shops may be used for drug trade and money laundering.

Tourism policy makers of a country play an important role in developing regulations to ensure tourists' security and stability through control over resource mobility, intervention in development of local and regional areas, and provision of a legal framework for production, environmental, and consumer protection (Williams, 2004). Nevertheless, in a corrupt country, the authorities often breach the country's tourism development policies with detrimental impact. For example, the Kenyan government failed to deal with environmental issues effectively and cooperate with local communities due to political corruption and constant changes in leadership, ensuing in a serious decline in ecotourism in the country (African Centre for Technology Studies [ACTS], 1998; Ikiara \& Okech, 2002).

Nevertheless, the existing literature of corruption and tourism demand reveals some mixed conclusions. On one hand, even though Lau and Hazari (2011) agreed that corruption can have negative impacts on tourism, they found that their estimation results are inconsistent with the theory. The corruption coefficients were estimated to be between 0.093 and 0.112 , suggesting that an increase in corruption 
perception index will not have adverse effects on tourism development. On the other hand, Das and Dirienzo (2010) found that a reduction in corruption levels generate positive impacts on the level of tourism competitiveness across nations. In fact, a decline in corruption level for developing countries increases their competitiveness greater than that for developed countries.

According to Southall and Robinson (2011), heritage tourism is defined as "visits to and experiences of places of historical importance and significance" (p. 177). It provides opportunities to visitors to reveal a country's identity and a symbol of national pride. Organizations such as UNESCO play an important role in promoting destination images and sustaining national inheritance. It seeks to encourage the identification, protection, and preservation of cultural and natural heritage globally, which are considered to have significant value to humanity (UNESCO, 2013).

Nevertheless, many of these treasures are susceptible to damage or destruction due to wars, constant terrorist attacks, and political riots. In fact, the restoration of these national heritages requires long-term planning and can be costly. Nuryanti (1996) claimed that developing countries face great challenges, particularly related to limited funding resources and management problems. Furthermore, Chheang (2008) argued that a developing country such as Cambodia had ruined its national treasures due to external intervention, French colonialism, and civil war. Unfortunately, despite the end of civil unrest in 1991, Chheang stressed that Cambodia's tourism remains underdeveloped due to corruption. As incidents of political upheaval and public corruption are mostly evident in developing countries, it is no doubt that heritage sites can be at risk of ruin. Hence, tourism officials in those politically uncertain countries should not only implement policies to preserve and protect heritage, they also need to impose appropriate crisis management to avoid the disappearance of heritage tourism.

\section{Data and Methodology}

In this article, we examine the impact of political instability on tourism demand by employing a fixedeffects panel data analysis for 139 countries over the period 1999-2009. The panel data models are advantageous because such data provide more information, more variability, less collinearity among the variables, more degrees of freedom, and more efficiency (Baltagi, 2008).

To our best knowledge, there are two empirical papers that have conducted investigations on political instability and corruption effects on tourism, respectively. The first is that of Neumayer (2004), who conducted an empirical investigation regarding political instability impacts on tourism using fixed effects and a dynamic generalized method of moments panel data models. ${ }^{1}$ The second by Lau and Hazari (2011) explored the relationship between corruption and tourism using panel ordinary least squares. Unlike the previous studies, the current article aims to develop an econometric model that quantifies the effects of political risk, terrorist threat, and corruption on tourism by controlling various economic variables. The new model is designed in such a way that it can avoid any omitted variable bias and can be used to generate reliable forecasts.

The current research is distinct from the data and models proposed by Neumayer (2004). In our study, we first identify political risk variables [i.e., internal conflicts (IC), government stability (GS), religion in politics (RP), ethnic tensions (ET), external conflicts (EC), and military in politics (MP)] that have significant influences on tourism demand data, which can then be used to create a composite index for political instability. Table 1 presents the description of political risk variables that are used in this study. Second, we incorporate historical and natural heritage in the model. Third, we extend and update the number of countries and period of analysis from previous study. Finally, we estimate the moderation effect of political instability and heritage to examine the role of UNESCO-listed heritage destinations in promoting the tourism industry.

We estimate the relationship between each political risk variable and tourism demand by using the following model:

$$
\ln \mathrm{TD}_{i t}=\delta_{0}+\delta_{1} X_{i t}+e_{i t}
$$

where $i=$ country; $t=$ time; TD = tourism demand; $\ln =$ natural logarithm; $X=$ the political risk indicator which can be taken as IC, GS, RP, EC, ET, MP, CORR or TERROR; $\delta_{k}=$ estimated coefficients for 
Table 1

Description of Political Risk Variables

\begin{tabular}{|c|c|c|}
\hline Notation & Variable name & Description \\
\hline GS & Government stability & $\begin{array}{l}\text { The variable presents the government's capability of carrying out its declared programs } \\
\text { and its ability to stay in office. Its subcomponents include government unity, legisla- } \\
\text { tive strength, and popular support. }\end{array}$ \\
\hline IC & Internal conflict & $\begin{array}{l}\text { It assesses political violence in a country and its actual or potential impact on governance. } \\
\text { The variable consists of two subcomponents: civil war/coup threat and civil disorder. }\end{array}$ \\
\hline EC & External conflict & $\begin{array}{l}\text { It measures the risk to the incumbent government from foreign action (i.e., diplomatic } \\
\text { pressures, territorial disputes) and violent external pressure such as cross-border con- } \\
\text { flicts and war. Three subcomponents are included in the variable: war, cross-border } \\
\text { conflict, and foreign pressures. }\end{array}$ \\
\hline CORR & Corruption & $\begin{array}{l}\text { This variable assesses corruption within the government, including excessive patronage, } \\
\text { nepotism, job reservation, favor for favors, secret party funding, and suspiciously } \\
\text { close ties between politics and business. }\end{array}$ \\
\hline MP & Military in politics & $\begin{array}{l}\text { It predicts the degree of military involvement in a government or the possibility of } \\
\text { military takeover an elected government. }\end{array}$ \\
\hline $\mathrm{RP}$ & Religion in politics & $\begin{array}{l}\text { The variable measures the extent of single religious group dominating governance and } \\
\text { the suppression of religious freedom. }\end{array}$ \\
\hline ET & Ethnic tensions & $\begin{array}{l}\text { The component assesses the degree of tensions due to racial, nationality, or language } \\
\text { divisions. In particular, it provides an index regarding the degree of tolerant level and } \\
\text { willingness to compromise by opposition group. }\end{array}$ \\
\hline TERROR & Terrorism & $\begin{array}{l}\text { This variable is separated from internal conflict so that we can examine how terrorism } \\
\text { can negatively impact on tourism demand. It is an index that presents the perceptions } \\
\text { of terrorist incidents in a country and whether terrorism is related to the country's } \\
\text { political violence. }\end{array}$ \\
\hline
\end{tabular}

Note: The description of the data is summarized and extracted from the PRS Group websites. For more detailed information, see http://www.prsgroup.com/ICRG_Methodology.aspx.

$k=0,1, \ldots, 9$, and $e_{i t}=$ error term. All political risk data are extracted from the International Country Risk Guide provided by the Political Risk Services (PRS) group. The data are constructed on the basis of point scores, which indicate that high (low) scores mean high (low) risk. ${ }^{2}$ For tourism demand data, we employ the number of tourist arrivals and tourism revenue earned in each country $i$, which are extracted from Euromonitor International. Based on the Equation 1, the expected sign of $\delta_{1}$ is negative, implying that the higher number of political unrest incidents in a country can cause serious decline in tourism demand.

Next, we extend Equation 1 by including countryspecific and economics variables, as shown in the following equation:

$$
\begin{aligned}
\operatorname{lnTD}= & \delta_{0}+\delta_{1} X_{i t}+\delta_{2} H+\delta_{3} N+ \\
& \delta_{4} \ln Y_{i t}+\delta_{5} \ln \mathrm{CEXC}_{i t}+ \\
& \delta_{6} \mathrm{IEXC}_{i t}+\delta_{7} \ln \mathrm{ATT}_{i t}+e_{i t}
\end{aligned}
$$

where $X=$ variables for political instability, corruption or terrorism; $H=$ country dummy variable for world historical heritage approved by UNESCO;
$N=$ country dummy variable for world natural wonders approved by UNESCO; $Y=$ real gross domestic product (GDP) per capita; $\mathrm{CEXC}=$ changes in real exchange rates; IEXC = initial exchange rate; ATT $=$ an indicator of tourist attractions. The model uses income and exchange rate indicators as the control variables. The income proxy variable is real GDP per capita, which measures the minimum income level that tourists could afford to travel to the country. It also represents a country's living standards and economic performance as an indication of the government's affordability to invest, build, and maintain infrastructures for tourism. Given the points above, we expect that the income coefficient sign should be positive. Changes in real exchange rates is the proxy variable for tourism price, which reflects the relative prices between origin and foreign countries (Lim, 2006). It is measured in national currency units per US dollar and adjusted by purchasing power parity, and the original real exchange rates are transformed into first difference data to avoid nonstationary issues. The expected sign for CEXC is positive. Furthermore, we adopt the initial exchange rate variable to distinguish countries 
that have high and low domestic currency values. The rational of using IEXC is to examine whether a country's strong currency could have adverse effects on its tourism competitiveness. We anticipate that if a country has a strong currency at the beginning, there is a tendency that the travel cost to the country is expensive and potential tourists would choose other destinations that can offer them cheaper deals and better value for money. Hence, the expected sign for IEXC coefficient will be negative. All income and exchange rate data are extracted from the Penn World Table. Our research includes country-specific variables such as tourist attractions, which measure a country's tourism revenues to visitors' sites, and permanent attractions such as art galleries, museums, casinos, and national parks. The data are provided by Euromonitor. The descriptive statistics for all variables can be found in the Appendix.

Finally, we examine the relationship between political instability and tourism demand in UNESCO's heritage countries using the interaction term of $X_{i t}$ and heritage dummy ( $H$ or $N$ ). For example, using the historical heritage dummy variable $(H)$, Equation 3 is structured as follows:

$$
\begin{aligned}
\ln \mathrm{TD}_{i t}= & \delta_{0}+\delta_{1} X_{i t}+\delta_{2} H+\delta_{3} X_{i t} \times H+ \\
& \delta_{4} \ln Y_{i t}+\delta_{5} \ln \mathrm{CEXC}_{i t}+ \\
& \delta_{6} \mathrm{IEXC}_{i t}+\delta_{7} \ln _{i t}+e_{i t}
\end{aligned}
$$

Differentiating Equation 3 with respect to $X_{\text {it }}$ shows the marginal impact of political instability as:

$$
\frac{\partial \ln T D_{i, t}}{\partial X_{i, t}}=\delta_{1}+\delta_{3} H
$$

A similar process applies to the $N$ variable. The interaction coefficient $\left(\delta_{3}\right)$ between $X_{i t}$ and $\operatorname{lnTD}$ it shows the relationship between political instability and tourism demand for countries that possess historical or natural heritage. The coefficient suggests that $X_{i t}$ decreases TD in historical heritage countries even though the impact is less compared to that of the nonheritage countries. We expect $\delta_{3}>0$ and $\left(\delta_{1}+\delta_{3}\right)<0$.

\section{Empirical Results}

This section analyzes the empirical results of the impact of political instability, terrorism, and corruption on tourism demand. The first part of the analysis focuses on the relationship between political instability (both individual and composite index), terrorism, and corruption with tourist arrival and tourism revenue only. The second part analyzes the effects after controlling several economic factors and with and without heritage variables by utilizing panel fixed effects.

How much do political instability, terrorism, and corruption matter for the tourism industry? To quantify this, we begin the analysis by estimating the impact of individual and composite indices of political instability and corruption index without controls on tourist arrival (TA) and tourism revenue (TR). The results are reported in Table 2 , suggesting that except for government stability (GS), all other individual as well as composite indices of political instability have negative and significant effects on TA and TR. For example, a one-unit increase in composite political instability index reduces TA and TR by $50 \%$ and $56 \%$, respectively. In other words, a higher political instability reduces tourist arrival and tourism revenue significantly and the magnitudes are considerable. In terms of individual components of political instability, internal conflict (IC), external conflict (EC), military in politics (MP), and ethnic tension (ET) play crucial roles in reducing tourist arrival and tourism revenue. Terrorism (TERROR) and corruption (CORR) also illustrate similar effects. A one-unit increase in TERROR and CORR reduces tourist arrivals by $16 \%$ and $35 \%$, respectively. Interestingly, terrorism has less impact than political instability and corruption as the responses of composite political instability and corruption are elastic. The rest of the analysis measures the impact on tourism development by using composite political instability index.

The next step estimates the impact of political instability, terrorism, and corruption on tourism development using panel period fixed-effect estimations after incorporating the standard economic controls in the tourism literature for 139 countries for the period 1999-2009. The results are reported in Table 3. The coefficient for political instability is negative and significant at the $1 \%$ level, indicating that higher political instability reduces tourist arrivals (TA) in a country. A one-unit increase in political instability decreases tourist arrivals by $24 \%$ when there is no heritage dummy variable; 
Table 2

Estimates and Elasticities of Political Instability Variables on Tourism Demand

\begin{tabular}{|c|c|c|c|c|}
\hline \multirow[b]{2}{*}{ Variables } & \multicolumn{2}{|c|}{ Estimates } & \multicolumn{2}{|c|}{ Elasticity } \\
\hline & $\ln (\mathrm{TA})$ & $\ln (\mathrm{TR})$ & TA & TR \\
\hline Composite of political instability (PI) & $\begin{array}{l}-0.695 * * * \\
(-0.058)\end{array}$ & $\begin{array}{l}-0.826 * * * \\
(-0.062)\end{array}$ & -2.313 & -2.749 \\
\hline Terrorism (TERROR) & $\begin{array}{l}-0.178 * * * \\
(-0.031)\end{array}$ & $\begin{array}{l}-0.162 * * * \\
(-0.036)\end{array}$ & -0.598 & -0.544 \\
\hline Government stability (GS) & $\begin{array}{c}-0.034 \\
(-0.032)\end{array}$ & $\begin{array}{l}-0.034 \\
(-0.05)\end{array}$ & -0.117 & -0.117 \\
\hline Internal conflicts (IC) & $\begin{array}{l}-0.734^{* * *} \\
(-0.037)\end{array}$ & $\begin{array}{l}-0.834^{* * *} \\
(-0.05)\end{array}$ & -2.003 & -2.276 \\
\hline External conflicts (EC) & $\begin{array}{l}-0.425 * * * \\
(-0.024)\end{array}$ & $\begin{array}{l}-0.614 * * * \\
(-0.061)\end{array}$ & -1.064 & -1.537 \\
\hline Military in politics (MP) & $\begin{array}{l}-0.403^{* * *} \\
(-0.003)\end{array}$ & $\begin{array}{l}-0.496 * * * \\
(-0.011)\end{array}$ & -1.666 & -2.05 \\
\hline Religion in politics (RP) & $\begin{array}{l}-0.194 * * * \\
(-0.01)\end{array}$ & $\begin{array}{l}-0.187 * * * \\
(-0.012)\end{array}$ & -0.606 & -0.584 \\
\hline Ethnics tension (ET) & $\begin{array}{l}-0.304 * * * \\
(-0.008)\end{array}$ & $\begin{array}{l}-0.379 * * * \\
(-0.012)\end{array}$ & -1.222 & -1.523 \\
\hline Corruption (CORR) & $\begin{array}{l}-0.43^{* * *} \\
(-0.008)\end{array}$ & $\begin{array}{l}-0.558 * * * \\
(-0.011)\end{array}$ & -2.634 & -3.419 \\
\hline
\end{tabular}

Note: TA, tourist arrival numbers; TR, tourism receipts. In denotes natural logarithm. Numbers in parentheses are standard errors. *** denotes significance at the $1 \%$ critical level. The elasticity value is derived as follows: For example, 0 where $a$ and $b$ are estimates. The first-order differentiation yields $\frac{d \mathrm{TA}}{d \mathrm{PI}}=b \mathrm{TA}$. Using the differentiation equation and including PI and TA variables, the elasticity equation is $E=\frac{\mathrm{PI}}{\mathrm{TA}} \cdot \frac{d \mathrm{TA}}{d \mathrm{PI}}=b \mathrm{PI}$. The mean of PI is used to calculate the elasticity value.

but it reduces further in the presence of historical and natural heritage (31\%). Likewise, the political instability coefficient retains the negative sign and the significance level when tourism revenue (TR) is used as the dependent variable. We found similar results when tourism revenue as a percentage of GDP is used; however, the results are not reported here due to space limitation. This result supports the $£ 2.5$ billion decline in tourism revenue in Egypt together with a $32 \%$ decrease in tourist arrivals to the region since the revolution erupted on January 25, 2011 (Shenker, 2012).

Likewise, the coefficient for CORR is negative and significant for the tourist arrivals as the dependent variable, suggesting that a high level of corruption reduces tourist arrivals significantly. The result is consistent with Lau and Hazari (2011) and Das and Dirienzo (2010). However, the effect becomes positive when heritage variables are included in the estimation. This result illustrates that an increase in corruption level would not have adverse influence on tourist arrival numbers, particularly for those countries that have historical and natural heritage. Perhaps, many experienced travelers have expectations that they would require paying bribes to corrupt authorities for travel visa or permits to some tourist destinations in order to make things accessible. For example, some tourist places or activities are restricted by the authorities in terms of available hours and numbers of tourists per day, which can be surmounted by paying bribes to the corrupt officials. Moreover, some tourist destinations require government approvals to enter into the spot, and bribing government officials can make things accessible. However, the corruption coefficient becomes negative and significant when TR is used as the dependent variable. Overall, the impact of corruption shows some interesting results on tourism demand. A higher level of corruption in a country might not indicate that the country's tourist numbers will 


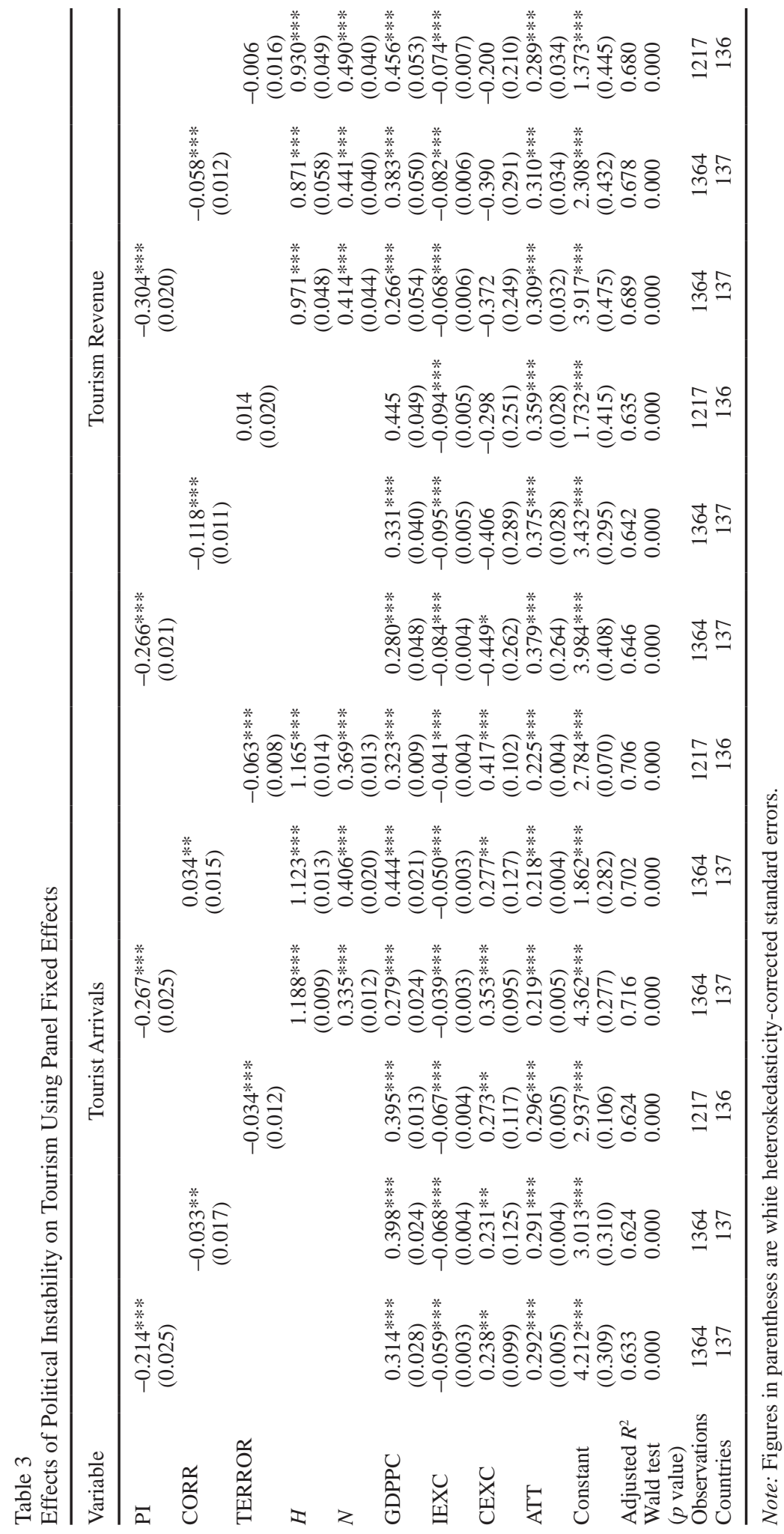


Table 4

Average Corruption Index and Growth in Tourism Demand From 1999 to 2009 for Selected Countries

\begin{tabular}{lcc}
\hline $\begin{array}{l}\text { Selected } \\
\text { Countries }\end{array}$ & $\begin{array}{c}\text { Average } \\
\text { Corruption Index }\end{array}$ & $\begin{array}{c}\text { Average } \\
\text { Percentage Growth } \\
\text { in Tourist Arrivals }\end{array}$ \\
\hline Turkey & 6.3 & 14.7 \\
Indonesia & 7.0 & 3.3 \\
Thailand & 7.5 & 5.1 \\
Czech Republic & 5.8 & 3.9 \\
Uganda & 7.0 & 17.6 \\
China & 7.3 & 6.0 \\
India & 6.6 & 7.9 \\
Switzerland & 3.1 & 1.2 \\
UK & 3.4 & 1.9 \\
Singapore & 3.4 & 4.4 \\
US & 3.7 & 1.5 \\
\hline
\end{tabular}

Note: For corruption index, a country that has the lowest (highest) level of corruption would have a low (high) score. The index ranges between 1 and 10. Sources: PRS Group and Euromonitor.

fall; nevertheless, there is a possibility that it can decrease tourism revenue. This result is consistent with countries like China, India, Indonesia, Thailand, and Turkey. Corruption index in these countries reflects a high level of corruption; however, the numbers of tourist arrivals to these countries are growing over time (see Table 4).

The coefficient for TERROR is negative and significant only when TA is the dependent variable. A one-unit increase in terrorists' activity decreases tourist arrivals by $4-7 \%$. On the other hand, the impact of terrorist attacks on tourism revenue is positive, although not significant, suggesting that terrorist attack may attract international as well as domestic tourists to witness the destruction or rebuild activity after terrorist attacks. The September 11 terrorist attack on the World Trade Center in New York City provides a good example of this positive effect. Now, when tourists visit New York City, they are also tempted to visit the reconstruction of Twin Towers.

The coefficients of $H$ and $N$ are positive and highly significant in all estimations, indicating that historical and natural heritage promote the tourism industry. Moreover, the control variables are significant and expected in signs with a few exceptions. A high level of per capita income and tourist attractions encourage the tourism demand of a country, whereas depreciation of currency promotes tourism. A low level of initial exchange rate attracts more tourists to a country due to cheaper currency.

Overall, political instability reduces tourism demand substantially. The magnitude of the effect on tourism revenue is stronger compared to the tourist arrivals (Table 5). The stronger effect may be due to tourism revenue consisting of both international and domestic tourists, whereas tourist arrivals contain only the international tourists. Control variables are all significant and expected in sign. Political instability, terrorism, and corruption with heritage dummy variables and control variables can explain around $62 \%$ to $72 \%$ of the variation in tourism demand (see Table 3). The implication of the results suggests that where political instability or terrorist attacks occur, it is a simple choice for the tourists to switch their travel destination to where there is a lower or no risk at all. The results

Table 5

Impact of Political Instability, Terrorism, and Corruption on Tourism Demand

\begin{tabular}{|c|c|c|c|c|}
\hline & \multicolumn{2}{|c|}{ Percentage Change in Tourist Arrivals } & \multicolumn{2}{|c|}{ Percentage Change in Tourism Revenue } \\
\hline & No heritage & Heritage & No heritage & Heritage \\
\hline PI & $-24 \%$ & $-31 \%$ & $-30 \%$ & $-36 \%$ \\
\hline CORR & $-3 \%$ & $+4 \%$ & $-13 \%$ & $-6 \%$ \\
\hline TERROR & $-4 \%$ & $-7 \%$ & $+1 \%$ & $-1 \%$ \\
\hline
\end{tabular}

Note: The figures shown are based on anti-natural logarithm of the coefficients from Table 3 minus one. For instance, in Table 3 , the regression for tourist arrival model without heritage dummy variables is $\ln (\mathrm{TA})=4.212-0.214 \mathrm{PI}+0.314 \mathrm{GDPPC}-0.059$ IEXC + 0.238CEXC + 0.292ATT. To measure the $\exp (0.214)-1=0.24$ percentage change in TA when PI changes by one unit, it can be calculated as: $\exp (0.214)-1=0.24$ or $24 \%$. 
also indicate that the deterring effect of political instability on tourism demand is far greater than the impact of terrorism and corruption. In addition, Table 3 reflects that historical and natural heritage attract more tourists and generate high tourism revenue in a country, but if there is political instability, then deterring effects are far greater compared to the countries that do not have any heritage.

Finally, after incorporating the interaction term, the sign of political risk variables remains the same; that is, high political risk causes damage to the tourism industry. The interaction term shows a positive sign with a few exceptions. The findings indicate that heritage plays an important role in attracting tourists. The marginal impact of PI on $\ln (\mathrm{TA})$ in historical heritage countries, for example, is $-0.263+(-0.063 \times 1)=-1.086$ (refer to Table 6$)$. That is, a one-unit rise in PI leads to a fall in $\ln (\mathrm{TA})$ coefficient by approximately 1.1. Outside heritage, a one-unit rise in PI leads to a fall in $\ln (\mathrm{TA})$ coefficient by approximately 0.1 . The marginal impacts are greater for historical heritage countries, which is consistent with our mediator effect results. However, for TERROR and CORR the marginal impacts are a little smaller in heritage destinations.

\section{Conclusion}

This article examines the performance of the tourism industry in terms of tourist arrivals and tourism revenue in the presence of political instability, corruption, and terrorism for 139 countries for the period 1999-2009 using panel fixed-effects estimation techniques. The results show that political instability seems to have an adverse effect on tourism industry. In other words, ceteris paribus, political instability, corruption, and terrorism have negative effects on tourism demand and the magnitudes of their effects are considerable. The negative effect varies from $1 \%$ to $36 \%$ on the tourism revenue, for example. Corruption shows some interesting effects, indicating that corruption might not reduce tourism demand in a country if it is classified as UNESCO's historical and natural heritage. Historical and natural heritage play crucial roles in attracting tourists to a country. However, even in the presence of heritage, political instability causes severe damage to the industry and the effects are stronger in comparison to terrorist attacks. Both causality (mediator) and interaction (moderator) effects show that heritage plays a vital role in promoting tourism industry even though there are various risks present in a country.

The policy implications of the study are twofold. First, for those countries that constantly face political uncertainty, tourism officials must put more emphasis on tourism crisis management to maintain confidence in tourists' security and to protect the countries' iconic treasures. Sönmez, Apotolopoulos, and Tarlow (1999) asserted that even though unpredictable terrorism acts and social unrest could happen anytime, destinations still need to be prepared with an action plan for recovery marketing strategies and fund-raising activities to conserve perishable tourism products. Second, the study estimated the losses of tourism revenue if countries experience political upheavals and terrorism. The estimations are robust after using several indicators, specifications, and estimation techniques. In the context of tourism demand modeling, it is important to include political instability, terrorism, and corruption variables as well as destinations' heritage indicators, so that forecasts about tourist arrivals and tourism revenues can be more accurate, which are vital to implementing effective plans for hotel and tourism development.

Table 6

Marginal Impacts (MIs) of Political Instability on Tourism for UNESCO’s Heritage Countries

\begin{tabular}{|c|c|c|c|c|c|c|c|c|c|c|c|c|}
\hline & \multicolumn{3}{|c|}{$\ln (\mathrm{TA})$ when $H=1$} & \multicolumn{3}{|c|}{$\ln (\mathrm{TA})$ when $N=1$} & \multicolumn{3}{|c|}{$\ln (\mathrm{TR})$ when $H=1$} & \multicolumn{3}{|c|}{$\ln (\mathrm{TR})$ when $N=1$} \\
\hline & $\delta_{1}$ & $\delta_{3}$ & MI & $\delta_{1}$ & $\delta_{3}$ & MI & $\delta_{1}$ & $\delta_{3}$ & MI & $\delta_{1}$ & $\delta_{3}$ & MI \\
\hline PI & -0.263 & -0.063 & -1.086 & -0.122 & -0.172 & -0.294 & -0.364 & +0.105 & -0.259 & -0.259 & +0.080 & -0.193 \\
\hline CORR & -0.017 & +0.073 & +0.056 & -0.033 & +0.062 & +0.029 & -0.130 & +0.126 & -0.004 & -0.175 & +0.148 & -0.027 \\
\hline TERROR & -0.072 & +0.007 & -0.065 & -0.075 & +0.097 & +0.022 & -0.021 & +0.018 & -0.003 & -0.082 & +0.211 & +0.129 \\
\hline
\end{tabular}

Note: Due to space limitation, we do not report the coefficients for other variables. However, we can provide them upon request. 
This study does not come without a limitation. The current research focused on past tourism data and not on potential tourists who intend to travel. As suggested by Hem, Iversen, and Nysveen (2002), destination images (i.e., advertisement photos) that portray a risky vacation situation could generally create negative effects on tourists' intention to visit a destination. Hence, for future research, it would be interesting to investigate how a destination's images of political risk, terrorist attacks, and corruption could influence potential tourists' intention to visit. It would not only explain the behavior and attitude of tourists' reactions to a destination's negative images, but it could also provide important information about the actual effects of political risk and corruption on future tourists. However, such research requires qualitative research methods that are beyond the scope of this study.

\section{Notes}

${ }^{1}$ Neumayer (2004) employed internal and external conflicts variables as the proxies for political instability, and real effective exchange rate as the economics variable.

${ }^{2}$ Note that the original scores provided by the PRS group interpret their political risk data as high (low) scores mean low (high) risks. For the ease of explanation, we rescale the PRS's score points, where high (low) scores mean high (low) risks.

Appendix

Descriptive Statistics of Tourism Demand and Political Instability Variables, 1999-2009

\begin{tabular}{|c|c|c|c|c|c|c|c|c|c|c|c|c|c|c|}
\hline & LTA & LTR & PI & GS & IC & EC & ET & MP & $\mathrm{RP}$ & Terror & Corr & EXC & LGDPPC & LATT \\
\hline Mean & 7.16 & 6.68 & 3.33 & 3.46 & 2.73 & 2.50 & 4.02 & 4.13 & 3.13 & 3.36 & 6.13 & 375.26 & 8.76 & 3.45 \\
\hline Median & 7.17 & 6.83 & 3.08 & 3.34 & 2.69 & 2.25 & 4 & 4 & 2.50 & 3.25 & 6.38 & 5.16 & 8.93 & 3.82 \\
\hline Max & 11.30 & 11.86 & 7.15 & 7.63 & 7.33 & 8.41 & 10 & 10 & 10 & 10 & 10 & 40290 & 11.84 & 11.42 \\
\hline Min & 1.74 & -13.82 & 1.28 & 1.38 & 1 & 1 & 1 & 1 & 1 & 1 & 1 & 0.20 & 5.09 & -13.82 \\
\hline SD & 1.92 & 2.35 & 1.12 & 1.15 & 1.18 & 1.11 & 1.92 & 2.57 & 1.94 & 1.94 & 1.77 & 2178.87 & 1.38 & 3.69 \\
\hline Skewness & -0.25 & -1.94 & 0.86 & 0.36 & 0.99 & 1.42 & 0.38 & 0.53 & 1.03 & 0.69 & -0.83 & 14.61 & -0.38 & -2.39 \\
\hline Kurtosis & 2.63 & 16.93 & 3.43 & 2.59 & 4.13 & 5.94 & 2.36 & 2.30 & 3.47 & 2.99 & 3.26 & 251.95 & 2.32 & 12.54 \\
\hline \multicolumn{15}{|l|}{ Jarque- } \\
\hline Bera & 23.85 & 13316.13 & 159 & 35.4 & 266 & 846 & 49.8 & 81.6 & 228 & 96.6 & 144.4 & 3185980 & 65.86 & 7254.06 \\
\hline Prob (JB) & 0.00 & 0.00 & 0.00 & 0.00 & 0.00 & 0.00 & 0.00 & 0.00 & 0.00 & 0.000 & 0.000 & 0.000 & 0.00 & 0.00 \\
\hline \multicolumn{15}{|c|}{ Panel unit root test (null hypothesis: panel series is nonstationary) } \\
\hline $\begin{array}{l}\text { LLC } t \\
\text { statistics }^{\mathrm{a}}\end{array}$ & -7.335 & -9.126 & -67 & -23 & -380 & -447 & -66 & -48 & -41 & -1437 & -641.7 & -8.33 & -4.79 & -8.59 \\
\hline $\begin{array}{l}\text { Prob } \\
\text { (LLC) }\end{array}$ & 0.000 & 0.000 & 0.00 & 0.00 & 0.00 & 0.00 & 0.00 & 0.00 & 0.00 & 0.000 & 0.000 & 0.000 & 0.000 & 0.000 \\
\hline
\end{tabular}

Note: LTA, natural logarithm of tourist arrivals; LTR, natural logarithm of tourism receipts; PI, composite of political instability; GS, government instability; IC, internal conflicts; EC, external conflicts; ET, ethics tension; MP, military in politics; RP, religion in politics; TERR, terrorism; CORR, corruption; EXC, real exchange rate (adjusted by PPP); LGDPPC, natural logarithm of gross domestic product per capita (adjusted by PPP); LATT, natural logarithm of tourist attraction.

${ }^{a} \mathrm{LLC} t$ statistics are based on the panel unit root tests.

\section{References}

African Centre for Technology Studies. (1998). What ails Kenya's policy on wildlife? Retrieved from http://www. aweer.org/in-depth/ind-what-ails-ke-pol.htm

Baker, K., \& Coulter, A. (2007). Terrorism and tourism: The vulnerability of beach vendors' livelihoods in Bali. Journal of Sustainable Tourism, 15(3), 249-266.

Baltagi, B. H. (2008). Econometric analysis of panel data. West Sussex, England: Wiley.

Bhattarai, K., Conway, D., \& Shrestha, N. (2005). Tourism, terrorism and turmoil in Nepal. Annals of Tourism Research, 32(3), 669-688.

Chheang, V. (2008). The political economy of tourism in Cambodia. Asia Pacific Journal of Tourism Research, 13(3), 281-297.

Darity, E. W. A. (2008). Indices of political instability (2nd ed.). Detroit, MI: Macmillan Reference.
Das, J., \& Dirienzo, C. (2010). Tourism competitiveness and corruption: A cross-country analysis. Tourism Economics, 16(3), 477-492.

Duffy, R. (2000). Shadow players: Ecotourism development, corruption and state politics in Belize. Third World Quarterly, 21(3), 549-565.

Euromonitor. (2011). Impact of Middle East turmoil on travel and tourism. Sydney, Australia: Author.

Fletcher, J., \& Morakabati, Y. (2008). Tourism activity, terrorism and political instability within the commonwealth: The cases of Fiji and Kenya. International Journal of Tourism Research, 10(6), 537-556.

Franks, J. (2009). Rethinking the roots of terrorism: Beyond orthodox terrorism theory-A critical research agenda. Global Society, 23(2), 153-176.

Garrod, B., \& Fyall, A. (2000). Managing heritage tourism. Annals of Tourism Research, 27(3), 682-708. 
Hall, C. M., \& O’Sullivan, V. (1996). Tourism, political stability and violence. In A. Pizam \& Y. Mansfeld (Eds.), Tourism, crime and international security issues (pp. 105-212). West Sussex, UK: Wiley.

Hem, L. E., Iversen, N. M., \& Nysveen, H. (2003). Effects of ad photos portraying risky vacation situations on intention to visit a tourist destination, Journal of Travel \& Tourism Marketing, 13(4), 1-26.

Hoti, S., McAleer, M., \& Shareef, R. (2005). Modelling country risk and uncertainty in small island tourism economies. Tourism Economics, 11(2), 159-183.

Hoti, S., McAleer, M., \& Shareef, R. (2007). Modelling international tourism and country risk spillovers for Cyprus and Malta. Tourism Management, 28(6), 1472-1484.

Ikiara, M., \& Okech, C. (2002). Impact of tourism on environment in Kenya: Status and policy. (Discussion Paper No. 19). Kenya: Kenya Institute for Public Policy Research and Analysis (KIPPRA).

Issa, I. A., \& Altinay, L. (2006). Impacts of political instability on tourism planning and development: The case of Lebanon. Tourism Economics, 12(3), 361-381.

Lagi, M., Bertrand, K. Z., \& Bar-Yam, Y. (2011). The food crises and political instability in North Africa and the Middle East. Retrieved from http://ssrn.com/ abstract $=1910031$

Lau, T. S. C., \& Hazari, B. R. (2011). Corruption and tourism. In B. R. Hazari \& R. Hoshmand (Eds.), Trade and welfare: Theoretical and empirical issues (pp. 159-170). New York: Nova.

Lim, C. (2006). A Survey of tourism demand modeling practice: Issues and implications. In L. Dwyer \& P. Forsyth (Eds.), International handbook on the economics of tourism (pp. 45-72), Northampton, England: Edward Elgar.

Llorca-Vivero, R. (2008). Terrorism and international tourism: New evidence, Defence and Peace Economics, 19(2), 169-188.

Mowforth, M., \& Munt, I. (2009). Tourism and sustainability: Development, globalisation and new tourism in the Third World (3rd ed.). New York: Routledge.

Munson, Z. (2008). Terrorism. Contexts, 7(4), 78-79.

Narayan, P. K. (2005). Did Rabuka’s military coups have a permanent effect or a transitory effect on tourist expenditure in Fiji: Evidence from Vogelsang's structural break test. Tourism Management, 26(4), 509-515.

Neumayer, E. (2004). The impact of political violence on tourism: Dynamic cross-national estimation. Journal of Conflict Resolution, 48(2), 259-281.

Nuryanti, W. (1996). Heritage and postmodern tourism. Annals of Tourism Research, 23(2), 249-260.

Pizam, A., \& Fleischer, A. (2002). Severity versus frequency of acts of terrorism: Which has a larger impact on tourism demand? Journal of Travel Research, 40(3), 337-339.

Shenker, J. (2012, January 19). Egyption frustration as tourists stay away. The Guardian. Retrieved from http:// www.guardian.co.uk/world/2012/jan/19/egypt-tourismvisitor-numbers-collapse

Song, H., \& Witt, S. F. (2006). Forecasting international tourist flows to Macau. Tourism Management, 27(2), 214-224.

Sönmez, S. F. (1998). Tourism, terrorism and political instability. Annals of Tourism Research, 25(2), 416-456.

Sönmez, S. F., Apostolopoulos, Y., \& Tarlow, P. (1999). Tourism in crisis: Managing the effects of terrorism. Journal of Travel Research, 38(13), 13-18.

Southall, C., \& Robinson, P. (2011). Heritage tourism. In P. Robinson, S. Heitmann, \& P. U. C. Dieke (Eds.), Research themes for tourism (pp. 176-187), London: CAB International.

Thompson, A. (2011). Terrorism and tourism in developed versus developing countries. Tourism Economics, 17(3), 693-700.

Tosun, C., \& Timothy, D. (2001). Shortcomings in planning approaches to tourism development in developing countries: The case of Turkey. International Journal of Contemporary Hospitality Management, 13(7), 352-359.

United Nations World Tourism Organization. (2006). Poverty alleviation through tourism: A compilation of good practices. Madrid, Spain: Author.

UNESCO (2013). World heritage list. Retrieved January 23, 2013, from http://whc.unesco.org/en/list/

Williams, A. M. (2004). Toward a political economy of tourism. In A. A. Lew, C. M. Hall, \& A. M. Williams (Eds.), A companion to tourism (pp. 61-73). Malden, MA: Blackwell.

Yaya, M. E. (2009). Terrorism and tourism: The case of Turkey. Defence and Peace Economics, 20(6), 477-497. 